\title{
Short communication: Pro- and antioxidative indicators in serum of dairy cows during late pregnancy and early lactation: Testing the effects of parity, different dietary energy levels, and farm
}

\author{
C. Urh, ${ }^{1}$ J. Denißen, ${ }^{2}$ E. Gerster ${ }^{3}$ N. Kraus, ${ }^{4}$ E. Stamer,${ }^{5}$ B. Heitkönig, ${ }^{1}$ H. Spiekers, ${ }^{6}$ and H. Sauerwein ${ }^{1 *}$ \\ ${ }^{1}$ University of Bonn, Institute for Animal Science, Katzenburgweg 7-9, 53115 Bonn, Germany \\ ${ }^{2}$ Chamber of Agriculture North Rhine-Westphalia, Center of Agriculture Haus Riswick, Elsenpaß 5, 47533, Kleve, Germany \\ ${ }^{3}$ Landwirtschaftliches Zentrum Baden-Württemberg (LAZBW), Atzenberger Weg 99, 88326 Aulendorf, Germany \\ ${ }^{4}$ Center for Agricultural Learning, Markgrafenstraße 1,91746 Weidenbach, Germany \\ ${ }^{5}$ TiDa Tier und Daten GmbH, Bosseer Str. 4c, 24259 Westensee/Brux, Germany \\ ${ }^{6}$ Bavarian State Research Center for Agriculture, Institute for Animal Nutrition and Feed Management, Prof.-Dürrwaechter-Platz 3, 85586 Poing, \\ Germany
}

\section{ABSTRACT}

Dairy cows face metabolic challenges in the transition from late pregnancy to early lactation. The energy demands for the growing fetus and the onset of milk production are increasing but voluntary feed intake often decreases around parturition and cannot meet these demands. This energy balance, among others, can change the oxidative status. Oxidative stress occurs when antioxidant defense mechanisms are not sufficient to cope with the increasing generation of reactive oxygen species. Our objectives were to investigate (1) the effect of parity on the oxidative status of dairy cows $(\mathrm{n}=247)$ in late pregnancy and early lactation; and (2) the effect of different inclusion rates of concentrate feeding (150 vs. $250 \mathrm{~g} / \mathrm{kg}$ of energy-corrected milk) during early lactation on 2 farms including 87 cows in total. In addition, we aimed to compare the oxidative status across the 2 farms using equal portions of concentrate feeding. For these purposes, we measured concentrations of the derivatives of reactive oxygen metabolites (dROM) and the ferric reducing ability (FRAP) in serum on $\mathrm{d}-50,-14,+8,+28$, and +100 relative to calving. Furthermore, we calculated the oxidative status index $(\mathrm{OSi})$ as dROM/FRAP $\times 100$. Data were analyzed using a linear mixed model. Cows in the first and second lactations had greater dROM, FRAP, and OSi than cows in their third and greater lactations. Hence, supporting the antioxidative side of the balance might be of particular importance in the first and second lactations. Feeding different amounts of concentrates did not affect dROM, FRAP, or OSi under our experimental conditions, suggesting that the

Received January 3, 2019.

Accepted March 6, 2019.

*Corresponding author: sauerwein@uni-bonn.de relatively small differences in energy intake were not affecting the oxidative status. Comparing farms, cows from one farm were notable for having greater dROM and lower FRAP, resulting in a greater OSi compared with cows on the other farm. Milk yield showed a time by farm interaction with $7 \%$ less milk on d 100 on the farm with the greater OSi. Moreover, cows on that farm had 1.4-fold greater $\beta$-hydroxybutyrate concentrations. Our results emphasize the value of assessing oxidative status with regard to both the pro- and antioxidative sides, and support the association between oxidative and metabolic status. Further investigations are needed to determine the applicability of OSi as a prognostic tool during early lactation and to determine which factors have the greatest influence on oxidative status.

Key words: dairy cow, oxidative status, parity, feeding concentrates, optiKuh

\section{Short Communication}

Dairy cows face metabolic challenges in the transition from late pregnancy to early lactation; for example, increasing energy demands for the growing fetus and the onset of milk production. In addition, systemic inflammation is an epiphenomenon of early lactation (Bradford et al., 2015). Oxidative stress is defined as the imbalance between pro-oxidants and antioxidants in an organism toward the pro-oxidative side (Sies, 1991). Reactive oxygen species are assumed to be produced proportionally to metabolic rate resulting from mitochondrial function and the electron transport chain (Monaghan et al., 2009; Speakman and Garratt, 2014). Oxidative stress is common in transition cows (Sordillo and Aitken, 2009). To characterize the pro-oxidative side, measuring derivatives of reactive oxygen metabolites (dROM) is a common option; dROM comprise oxygen-centered free radicals 
and nonradical derivatives that are normal byproducts of cellular metabolism (Reilly et al., 1991). They are important in several physiological processes such as protein phosphorylation, apoptosis, cell immunity, and others (Agarwal et al., 2005). Apart from that, they can impair cell functions by affecting cellular lipids, proteins, and DNA if they are produced in excess and the antioxidative defense is insufficient (Miller et al., 1993; Sugino, 2006). The antioxidative defense comprises enzymatic and nonenzymatic components. Enzymatic antioxidants such as superoxide dismutase and glutathione peroxidase represent the main intracellular defense, and nonenzymatic antioxidants such as sulfhydryl groups of albumin, $\alpha$-tocopherol, and uric acid represent the main extracellular defense (Miller et al., 1993; Urban-Chmiel, 2006; Halliwell and Gutteridge, 2015). Assessing individual antioxidative compounds is very laborious; therefore, methods to assess the antioxidant capacity of serum as a function of their overall activity has been suggested (Cao and Prior, 1998); for example, the ferric reducing ability of plasma (FRAP; Benzie and Strain, 1996). To detect changes in oxidative status, both sides of the oxidative status should be assessed (Sharma et al., 1999). Abuelo et al. (2013) suggested the oxidative status index (OSi) as a tool to assess the redox status in dairy cattle during the transition period. The OSi is calculated as the ratio of pro-oxidant to antioxidant capacity. Oxidative status increases postpartum because of an increase in metabolic activity and systemic inflammation and thus enhanced accumulation of $\mathrm{dROM}$ and, at the same time, depletion of the antioxidant compounds (Sordillo and Aitken, 2009; Abuelo et al., 2013).

When considering assessments of oxidative status beyond strictly controlled experiments, potential confounding factors need to be evaluated. We hypothesized that cows in their first lactation would have a greater OSi related to their greater metabolic activity for their own body growth. Moreover, we hypothesized that increasing the portion of concentrate in the diet would elevate the OSi, and that cows on different farms fed similar rations would not differ in OSi.

Therefore, our objectives were to investigate the effect of parity on the oxidative status of dairy cows in late pregnancy and early lactation. Primiparous cows are still growing at the time of their first calving and therefore face different metabolic challenges around parturition than pluriparous cows (Coffey et al., 2006; Wathes et al., 2007). We also aimed to test the effect of different energy levels in the lactation diet by feeding different amounts of concentrate during early lactation in 2 different farms. Increasing the dietary level of starch was reported to increase oxidative status (Gabai et al., 2004); thus, the amount and portion of concen- trates in the diet might need to be considered when aiming to assess oxidative status. Finally, we aimed to test the effect of farm under similar feeding conditions.

The animal experiments were conducted between 2014 and 2017 at 3 experimental dairy farms in Germany as part of the national project "optiKuh." The experiments were approved by the responsible local authorities for animal welfare affairs and therefore, were carried out in accordance with EU Directive 2010/63/ EU and the German Animal Protection Law. All cows were housed in freestall barns, had permanent free access to feed and water and were milked twice daily (farm A: 0500 and $1630 \mathrm{~h}$; farm B: 0545 and $1630 \mathrm{~h}$; farm C: 0530 and $1515 \mathrm{~h}$ ). Milk yield was recorded daily and milk components were analyzed weekly (Denissen et al., 2018).

For the first objective, investigating the effect of parity, we analyzed data from 257 Holstein dairy cows from one experimental farm (farm A). Cows were fed according to the recommendations of the Society of Nutrition Physiology in Germany (GfE, 2001). For the second and third objectives, investigating the effect of feeding different amounts of concentrates and the differences between farms, samples and data from Simmental cows (lactation number $\geq 3$ ) on 2 experimental farms (farms $\mathrm{B}$ and $\mathrm{C}$ ) were considered. During the dry periods, all animals were fed the farm-specific ration according to the recommendations of the GfE (2001). During lactation, cows were fed roughage containing 6.5 MJ of $\mathrm{NE}_{\mathrm{L}} /$ $\mathrm{kg}$ of DM and either $150 \mathrm{~g}$ (farm B: $\mathrm{n}=24$; farm C: $\mathrm{n}$ $=19$ ) or $250 \mathrm{~g}$ (farm B: $\mathrm{n}=25$; farm $\mathrm{C}: \mathrm{n}=19$ ) of concentrate $/ \mathrm{kg}$ of ECM yield. The feed was offered as a TMR in farm B and as partial mixed ration (PMR) in farm $\mathrm{C}$. The components and chemical composition of the diets are shown in Table 1. The ECM was calculated using the following equation by the GfE (2001):

$$
\begin{gathered}
\mathrm{ECM}(\mathrm{kg} / \mathrm{d})=\text { milk yield }(\mathrm{kg} / \mathrm{d}) \times[(1.05+0.38 \\
\times \text { milk fat } \%+0.21 \times \text { milk protein } \%) / 3.28]
\end{gathered}
$$

Individual feed intake was measured daily with weighing troughs and BCS was assessed monthly using a 5-point scale with 0.25-point increments (Edmonson et al., 1989). Blood samples were collected after the morning milking (between 0800 and $1100 \mathrm{~h}$ ) from a jugular vein on the following days relative to calving [desired day $( \pm$ accepted range of deviation) $]:-50( \pm 10) \mathrm{d}$, $-14( \pm 4) \mathrm{d},+8( \pm 2) \mathrm{d},+28( \pm 2) \mathrm{d}$, and $+100( \pm 4) \mathrm{d}$. Samples were allowed to clot at 20 to $25^{\circ} \mathrm{C}$ for 60 to $90 \mathrm{~min}$ and then centrifuged at $1,800 \times g$ for $10 \mathrm{~min}$. Serum samples were stored at $-20^{\circ} \mathrm{C}$ until analyzed.

Serum concentrations of dROM were measured with $\mathrm{N}, \mathrm{N}$-diethyl-para-phenylenediamine as chromogenic 
substrate (Alberti et al., 2000) with modifications according to Regenhard et al. (2014). The results are expressed as $\mathrm{H}_{2} \mathrm{O}_{2}$ equivalents. The mean intra-assay coefficient of variation (CV) was $2.9 \%$ and the interassay CV was $11.8 \%$. The FRAP was measured according to Benzie and Strain (1996). The standard curve included 7 points $(0.05,0.1,0.2,0.3,0.4,0.6$, and $0.8 \mathrm{mM} \mathrm{FeSO}{ }_{4} \cdot 7 \mathrm{H}_{2} \mathrm{O}$; concentrations were given as $\mathrm{m} M$ $\mathrm{Fe}^{2+}$ ). The mean intra-assay CV was $1.1 \%$ and the interassay CV was $0.5 \%$. The OSi was calculated as dROM/ FRAP $\times 100\left[\left(\mu \mathrm{g}\right.\right.$ of $\mathrm{H}_{2} \mathrm{O}_{2} / \mathrm{mL}$ per $\left.\left.\mathrm{m} M \mathrm{Fe}^{2+}\right) \times 100\right]$. Serum concentrations of nonesterified fatty acids (NEFA) and BHB were analyzed photometrically with a Cobas Mira analyzer (Hoffmann-La Roche, Basel, Switzerland). Data were analyzed using SPSS (IBM SPSS Statistics 25, Ehningen, Germany). Cow was set as random effect in all models. A first analysis with lactation number as fixed effect revealed that cows in first and second lactations did not differ from each other in their oxidative status but that they did differ compared with cows in greater lactations. Therefore, parity was dichotomized into cows in their first and second lactation $(\mathrm{n}=133$; mean lactation number: 1.4 \pm 0.04 ; mean age: $28 \pm 0.6 \mathrm{mo}$ ) and cows in their third and greater lactation $(\mathrm{n}=114$; mean lactation number: $4.5 \pm 0.15$; mean age: $70 \pm 2 \mathrm{mo}$ ). Bonferroni adjustment was used for post hoc analyses. The linear mixed model for investigating the parity effect was

$$
y_{i j k}=\mu+T_{i}+P_{j}+T P_{i j}+i_{k}+e_{i j k}
$$

where $y_{i j k}=$ response variable, $\mu=$ overall mean, $T_{i}=$ fixed time effect $(i=\mathrm{d}-50,-14,+8,+28,+100), P_{j}$ $=$ fixed parity effect $(j=$ first and second lactations, $\geq$ third lactation), $T P_{i j}=$ fixed interaction, $i_{k}=$ random effect of the individual cow $(k=1, \ldots, 247)$, and $e_{i j k}=$ residual error.

The linear mixed model for investigating the feeding and farm effect was

$$
\begin{gathered}
y_{i j k l}=\mu+T_{i}+C_{j}+F_{k}+T C_{i j}+T F_{i k} \\
+C F_{j k}+i_{l}+e_{i j k l},
\end{gathered}
$$

where $y_{i j k l}=$ response variable, $\mu=$ overall mean, $T_{i}=$ time effect $(i=\mathrm{d}+8,+28,+100), C_{j}=$ concentrate effect $(j=150 \mathrm{~g} / \mathrm{kg}$ of ECM, $250 \mathrm{~g} / \mathrm{kg}$ of ECM $), F_{k}=$ farm effect $\left(k=\right.$ farm B, farm C), $T C_{i j}, T F_{i k}$, and $C F_{j k}$ $=$ fixed interactions, $i_{l}=$ random effect of the individual cow $(l=1, \ldots, 87)$, and $e_{i j k l}=$ residual error. The 3-way interaction between time, treatment, and farm was not significant for any of the tested response variables and was, therefore, excluded from the model. The assumptions for the linear mixed model, in terms of normal distribution and homoscedasticity of the residuals were met. Results are presented as means \pm standard error of the means. Significance was declared at $P<0.05$.

The results for dROM, FRAP, and OSi in farm A are shown in Figure 1. The dROM, FRAP, and OSi showed similar trends over time for cows in all lactations and were lowest during prepartum and increased until d 8, remaining at this level for the subsequent sampling time points. The increased OSi postpartum observed is in accordance with the study of Abuelo et al. (2013), although those authors did not detect differences when looking at pro- and antioxidative variables separately. The rapid increase of milk yield and insufficient feed intake early postpartum might enhance the production of reactive oxygen species, for example, because of increased metabolic activity and lipid peroxidation (Castillo et al., 2005; Sordillo and Aitken, 2009). Ad-

Table 1. Chemical composition and proportions of concentrates in rations in farms $\mathrm{B}$ and $\mathrm{C}^{1}$

\begin{tabular}{lcrrr}
\hline Item & \multicolumn{2}{c}{ Farm B (TMR) } & \multicolumn{2}{c}{ Farm C (PMR) } \\
\hline Concentrate (g/kg of ECM) & 150 & 250 & 150 & 250 \\
Concentrate portion (\% of DM) & 22 & 35 & 31 & 38 \\
DM (g/kg) & 429 & 468 & 466 & 514 \\
Chemical composition (g/kg of DM) & & & & \\
Crude ash & 80 & 79 & 71 & 70 \\
Crude protein & 152 & 157 & 158 & 159 \\
Crude fat & 30 & 28 & 45 & 44 \\
Crude fiber & 195 & 172 & 177 & 167 \\
aNDF $_{\text {OM }}$ & 346 & 310 & 377 & 362 \\
ADF $_{\text {3 }}$ & 223 & 197 & 222 & 212 \\
Energy (MJ of NE $/ \mathrm{kg}$ of DM) & 6.72 & 6.96 & 6.76 & 6.82 \\
Energy (MJ of $\mathrm{ME} / \mathrm{kg}$ of DM) & 11.0 & 11.3 & 11.1 & 11.1 \\
\hline
\end{tabular}

${ }^{1}$ Values are presented as means over the study period (1-100 DIM) in the respective farms. Rations were either provided as TMR or partial mixed ration (PMR).

${ }^{2} \mathrm{NDF}$ in $\mathrm{OM}$; that is, without residual ash and pretreated with amylase.

${ }^{3} \mathrm{ADF}$ without residual ash. 
ditionally, antioxidants are likely depleted prepartum to some extent because of the production of colostrum (Goff and Stabel, 1990) and to balance the increased oxidants (Abuelo et al., 2013). Nevertheless, the effect of this oxidative status on milk yield and health might be not critical (Wullepit et al., 2009) and needs to be evaluated together with clinical data. In our study, cows in their first and second lactations had greater dROM, FRAP, and OSi than cows in their third or higher lactations. Only a few studies are available on the oxidative status in cows of different parities. Abuelo et al. (2016) reported greater pro-oxidant production in primiparous cows than in pluriparous cows, whereas Elischer et al. (2015) demonstrated that primiparous cows had a greater antioxidant potential. In contrast, Omidi et al. (2017) reported a lower total antioxidant capacity for primiparous cows than pluriparous cows.

The individual variation (Castillo et al., 2005) and the variation between studies in oxidative status emphasizes the importance of assessing both the pro-oxidant and antioxidant sides, to obtain a more precise picture of oxidative status in dairy cows. Greater levels of prooxidants might not always equal greater oxidative stress but could be controlled by greater antioxidant capacity. Our results suggest that not only cows in first lactation but also those in second lactation should be evaluated with regard to potential burdens arising from increased oxidative status.

Results of the feeding trial are shown in Figure 2. Feeding different amounts of concentrates did not affect dROM, FRAP, or OSi. Previous studies have shown an increase in oxidative status related to high starch contents in the diet of dairy cows (Gabai et al., 2004) and ewes (Sgorlon et al., 2008). Pedernera et al. (2010) reported an indirect effect of diet on oxidative status in a study with pasture-based feeding. When they compared cows with greater mobilization of body reserves, cows fed more concentrate had lower antioxidant capacity than cows fed less concentrate. Cows with medium or low mobilization of body reserves showed no differences in oxidative status related to diet (Pedernera et al., 2010). The difference between the amounts of concentrates in our study might not have been great enough to affect oxidative status; the recommendations of GfE (2001) were still met in both groups. The BHB concentrations (Table 2) were not affected by the different inclusion rates of concentrate (mean from d 8 to 100: $150 \mathrm{~g} / \mathrm{kg}$ ECM group: $0.67 \pm 0.05 \mathrm{mmol} / \mathrm{L} ; 250 \mathrm{~g} / \mathrm{kg}$ ECM group: $0.66 \pm 0.05 \mathrm{mmol} / \mathrm{L} ; P=0.9$ ). Greater NEFA concentrations for cows in the $150 \mathrm{~g} / \mathrm{kg}$ of ECM group $(566 \pm 27 \mu \mathrm{mol} / \mathrm{L})$ indicated a greater mobilization of body reserves compared with cows in the $250 \mathrm{~g} /$ $\mathrm{kg}$ of ECM group (NEFA: $468 \pm 0.01 \mu \mathrm{mol} / \mathrm{L} ; P=$ $0.01)$.

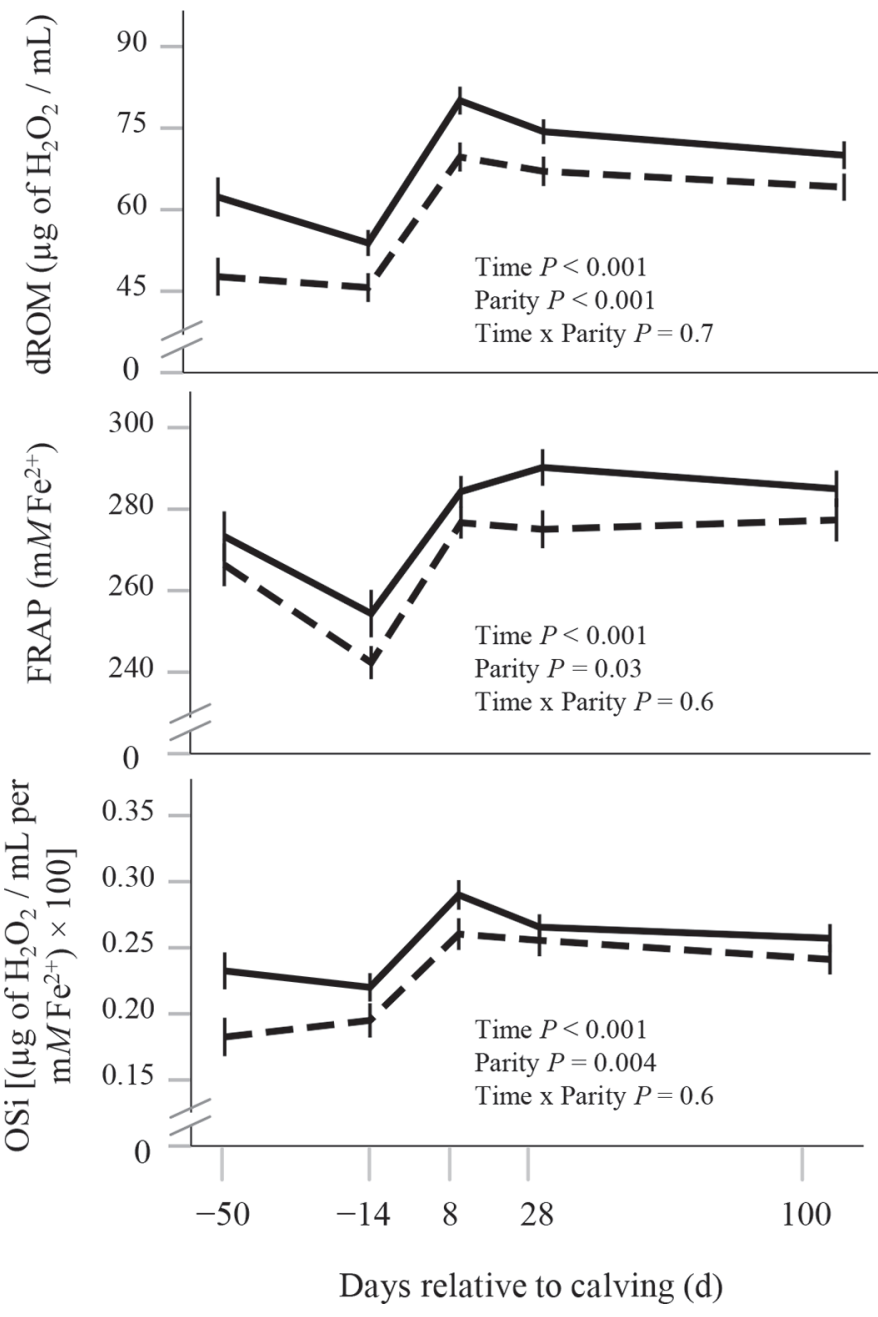

Figure 1. Mean $( \pm \mathrm{SEM})$ serum concentrations of derivatives of reactive oxygen metabolites (dROM) and ferric reducing ability (FRAP) and their ratio $(\mathrm{OSi})$ on farm $\mathrm{A}$ for Holstein cows in their first and second lactations (solid lines, $\mathrm{n}=133$ ) and in their third or higher lactation (dashed lines, $\mathrm{n}=114)$. $P$-values from the linear mixed model for the fixed effects of time, parity, and the interaction between time and parity are presented.

In our study, all 3 variables for oxidative status differed between the 2 farms compared directly, with greater dROM, lower FRAP, and a greater OSi on farm $\mathrm{B}$ than on farm C. To avoid intermingling of breed and feeding with the farm effect, we only compared farms $\mathrm{B}$ and $\mathrm{C}$ to investigate the farm effect. There was an interaction between time and farm for FRAP, resulting from a $12 \%$ increase from d 8 to d 100 on farm C, whereas FRAP in farm B remained lower during the study period.

The differences between the farms might be explained, to some extent, by individual variation, as noted by Castillo et al. (2005). In comparing oxidative status between different farms, Abuelo et al. (2015) reported a 
greater OSi on organically managed farms than on conventionally managed farms but no differences between 2 organically managed farms. They suggested that the different external supply of antioxidants explained the lower antioxidant capacity on the organically managed farms (Abuelo et al., 2015). The amount of antioxidants (e.g., vitamin E and selenium) in the roughage of the 2 farms in our study might have varied and could have affected the cows' antioxidant capacity. However, because both farms provided mineral and vitamin mix to their herds to cover dietary needs, it is unlikely that divergent supply would account for the differences in
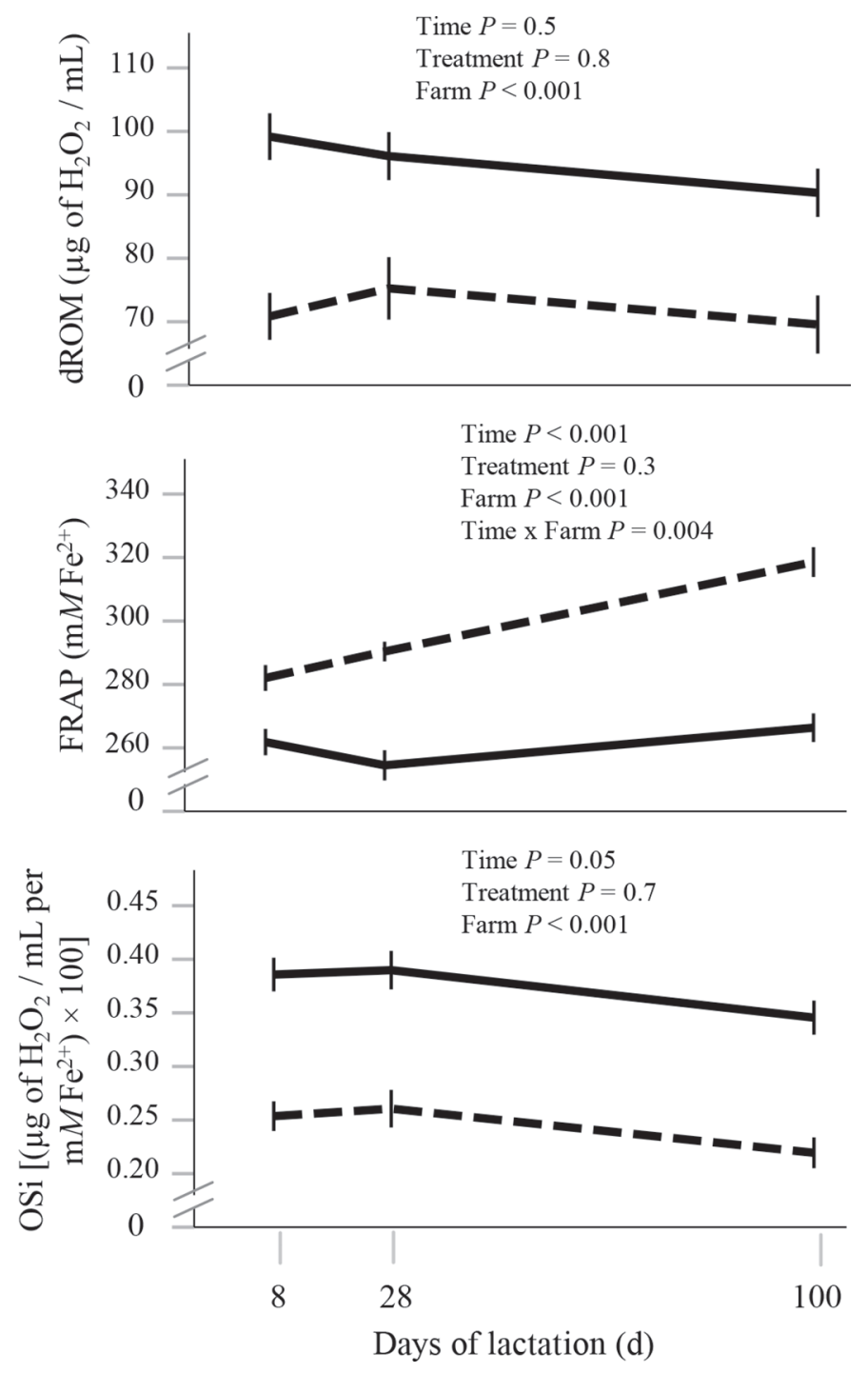

Figure 2. Mean $( \pm$ SEM $)$ serum concentrations of derivatives of reactive oxygen metabolites (dROM) and ferric reducing ability (FRAP) and their ratio $(\mathrm{OSi})$ of all cows, irrespective of feeding group, in farm B (solid lines, $\mathrm{n}=49$ ) and farm $\mathrm{C}$ (dashed lines, $\mathrm{n}=38$ ) with Simmental cows. $P$-values from the linear mixed model for the fixed effects of time, treatment, farm, and significant interactions between these effects are presented. the oxidative status between the farms. When comparing milk yields (at $100 \mathrm{~d}$ ) between the 2 farms with divergent oxidative status, we found an interaction between time and farm, which resulted from greater yields in farm $\mathrm{B}$ on $\mathrm{d} 8(33.9 \pm 0.8 \mathrm{~kg} / \mathrm{d})$ but lower milk yield on d $100(33.8 \pm 0.8 \mathrm{~kg} / \mathrm{d})$ compared with farm C (d 8: $32.2 \pm 0.8 \mathrm{~kg} / \mathrm{d}$; d 100: $36.4 \pm 0.8 \mathrm{~kg} / \mathrm{d})$. The lower milk yield on $100 \mathrm{~d}$ might be related to the greater oxidative status that the cows on farm B experienced. In agreement, Pedernera et al. (2010) reported a greater OSi related to lower milk yield. For the cows in our study, Spiekers et al. (2018) reported a higher energy expenditure per kilogram of ECM on farm B than on farm C. Although the cows on farm B had greater intake of DM and energy, their BCS loss from d 28 to 100 tended to be greater $(-0.2$ BCS points) than that on farm $\mathrm{C}(-0.1 \mathrm{BCS}$ points, time $\times$ farm: $P=0.079$ ). Bernabucci et al. (2005) stated that cows with greater BCS loss are more sensitive to oxidative stress and reported a positive association between oxidative status with NEFA and BHB as indicators for lipomobilization and ketogenesis. In our study, cows on farm B had 1.3-fold greater BHB concentrations $(0.76$ $\pm 0.04 \mathrm{mmol} / \mathrm{L})$ compared with those on farm $\mathrm{C}(0.57$ $\pm 0.05 \mathrm{mmol} / \mathrm{L} ; P=0.003)$ but the mean BHB concentrations were below the critical value of $1.2 \mathrm{mmol} / \mathrm{L}$ (Dirksen et al., 2012) in both farms at all time points tested. Concentrations of NEFA did not differ between the farms (farm B: $516 \pm 26 \mu \mathrm{mol} / \mathrm{L}$; farm C: $518 \pm 29$ $\mu \mathrm{mol} / \mathrm{L} ; P=0.97)$. Hence, the greater oxidative status on farm B might indicate a metabolic or health problem, on which the cows had to spent additional energy, resulting in lower milk yields and greater loss of BCS toward d 100. However, the relatively small number of animals and farms is a limitation of our study and the question of the causal connection and its direction between the different variables remain unclear. Further investigations including a greater number of farms and animals are needed to narrow down the reasons for the individual farm-level differences. For example, management factors, such as rearing of heifers, likely plays an important role in the oxidative status of animals (Celi, 2011). In a further step, the suitability of OSi in early lactation as a prognostic tool for metabolic health or milk yield in the ongoing lactation should be investigated.

In conclusion, our results emphasize the value of investigating both sides of the pro- and antioxidant balance because greater concentrations of pro-oxidants might not always result in greater oxidative status but might be controlled by a greater antioxidant capacity. Moreover, not only is special management of primiparous cows important, but cows in their second lactation also need to be regarded with special care related to 
Table 2. Mean $\left( \pm\right.$ SEM) concentrations of blood variables in cows (lactation number $\geq 3$ ) from the feeding trial ${ }^{1}$

\begin{tabular}{|c|c|c|c|c|c|c|}
\hline Blood variable $^{2}$ & $\mathrm{MC}$ & $\mathrm{HC}$ & $P$-value & Farm B & Farm C & $P$-value ${ }^{3}$ \\
\hline FRAP $^{3}$ & $280 \pm 4$ & $274 \pm 4$ & 0.3 & $258 \pm 4$ & $296 \pm 4$ & $<0.001$ \\
\hline $\mathrm{OSi}^{4}$ & $0.31 \pm 0.02$ & $0.32 \pm 0.02$ & 0.7 & $0.38 \pm 0.01$ & $0.24 \pm 0.02$ & $<0.001$ \\
\hline $\mathrm{BHB}(\mathrm{mmol} / \mathrm{L})$ & $0.67 \pm 0.05$ & $0.66 \pm 0.05$ & 0.9 & $0.76 \pm 0.04$ & $0.57 \pm 0.05$ & 0.003 \\
\hline Insulin $(\mu \mathrm{U} / \mathrm{mL})$ & $10 \pm 0.9$ & $12.4 \pm 1$ & 0.065 & $11 \pm 0.9$ & $11.4 \pm 1$ & 0.7 \\
\hline Glucose $(\mathrm{mmol} / \mathrm{L})$ & $3.15 \pm 0.04$ & $3.22 \pm 0.04$ & 0.3 & $3.38 \pm 0.04$ & $2.98 \pm 0.04$ & $<0.001$ \\
\hline
\end{tabular}

${ }^{1}$ Values are presented as means over the study period (1-100 DIM) in the respective feeding group $(\mathrm{MC}$ or $\mathrm{HC})$ or farm $(\mathrm{B}$ or $\mathrm{C}) . \mathrm{MC}=\mathrm{medium}$ concentrate group receiving $150 \mathrm{~g}$ of concentrate $/ \mathrm{kg}$ of $\mathrm{ECM}$ yield; $\mathrm{HC}=$ high concentrate group receiving $250 \mathrm{~g}$ of concentrate $/ \mathrm{kg}$ of ECM yield. Additional measurements were performed as described in Urh et al. (2019).

${ }^{2} \mathrm{dROM}=$ derivatives of oxygen metabolites; FRAP $=$ ferric reducing ability of plasma; OSi $=$ oxidative status index; NEFA $=$ nonesterified fatty acids.

${ }^{3} P$-values are from the linear mixed model with the fixed effects time, feeding group, farm, and all 2-way interactions, and the random effect of cow.

their greater oxidative status. Further investigations are needed to find out which factors, in management for example, have the greatest influence on oxidative status and result in farm individual variation. Furthermore, the suitability of the OSi as prognostic marker in early lactation should be investigated.

\section{ACKNOWLEDGMENTS}

The project "optiKuh" was supported by funds of the Federal Ministry of Food and Agriculture (BMEL) based on a decision of the Parliament of the Federal Republic of Germany via the Federal Office for Agriculture and Food (BLE) under the innovation support program (grant number 2817201013).

\section{REFERENCES}

Abuelo, A., J. C. Gandy, L. Neuder, J. Brester, and L. M. Sordillo. 2016. Short communication: Markers of oxidant status and inflammation relative to the development of claw lesions associated with lameness in early lactation cows. J. Dairy Sci. 99:5640-5648. https: //doi.org/10.3168/jds.2015-10707.

Abuelo, A., J. Hernández, J. L. Benedito, and C. Castillo. 2013. Oxidative stress index (OSi) as a new tool to assess redox status in dairy cattle during the transition period. Animal 7:1374-1378. https://doi.org/10.1017/S1751731113000396.

Abuelo, A., J. Hernández, J. L. Benedito, and C. Castillo. 2015. A pilot study to compare oxidative status between organically and conventionally managed dairy cattle during the transition period. Zuchthygiene 50:538-544. https://doi.org/10.1111/rda.12519.

Agarwal, A., S. Gupta, and R. K. Sharma. 2005. Role of oxidative stress in female reproduction. Reprod. Biol. Endocrinol. 3:28. https://doi.org/10.1186/1477-7827-3-28.

Alberti, A., L. Bolognini, D. Macciantelli, and M. Caratelli. 2000. The radical cation of N,N-diethyl-para-phenylendiamine: A possible indicator of oxidative stress in biological samples. Res. Chem. Intermed. 26:253-267. https://doi.org/10.1163/156856700X00769.

Benzie, I. F., and J. J. Strain. 1996. The ferric reducing ability of plasma (FRAP) as a measure of "antioxidant power": the FRAP assay. Anal. Biochem. 239:70-76. https://doi.org/10.1006/abio .1996 .0292 .
Bernabucci, U., B. Ronchi, N. Lacetera, and A. Nardone. 2005. Influence of body condition score on relationships between metabolic status and oxidative stress in periparturient dairy cows. J. Dairy Sci. 88:2017-2026. https://doi.org/10.3168/jds.S0022 -0302(05)72878-2.

Bradford, B. J., K. Yuan, J. K. Farney, L. K. Mamedova, and A. J. Carpenter. 2015. Invited review: Inflammation during the transition to lactation: New adventures with an old flame. J. Dairy Sci. 98:6631-6650. https://doi.org/10.3168/jds.2015-9683.

Cao, G., and R. L. Prior. 1998. Comparison of different analytical methods for assessing total antioxidant capacity of human serum. Clin. Chem. 44:1309-1315.

Castillo, C., J. Hernandez, A. Bravo, M. Lopez-Alonso, V. Pereira, and J. L. Benedito. 2005. Oxidative status during late pregnancy and early lactation in dairy cows. Vet. J. 169:286-292. https://doi.org/ 10.1016/j.tvjl.2004.02.001.

Celi, P. 2011. Oxidative stress in ruminants. Pages 191-231 in Studies on Veterinary Medicine. L. Mandelker and P. Vajdovich, ed. Humana Press, Totowa, NJ.

Coffey, M. P., J. Hickey, and S. Brotherstone. 2006. Genetic aspects of growth of Holstein-Friesian dairy cows from birth to maturity. J. Dairy Sci. 89:322-329. https://doi.org/10.3168/jds.S0022 -0302(06)72097-5.

Denissen, J., S. Beintmann, S. Hoppe, E. Stamer, H. Spiekers, M. Pries, and K.-H. Südekum. 2018. Effects of energy density of forage and amount of concentrates on feed intake, rumination behaviour and performance of German Holstein cows during a whole lactation. Zuchtungskunde 90:430-432.

Dirksen, G., H.-D. Gründer, and M. Stöber. 2012. Die klinische Untersuchung des Rindes [The clinical investigation of bovine animals]. 4. Aufl., unveränderter Nachdr. der 3. Aufl. Enke, Stuttgart, Germany.

Edmonson, A. J., I. J. Lean, L. D. Weaver, T. Farver, and G. Webster. 1989. A body condition scoring chart for Holstein dairy cows. J. Dairy Sci. 72:68-78. https://doi.org/10.3168/jds.S0022 $-0302(89) 79081-0$.

Elischer, M. F., L. M. Sordillo, J. M. Siegford, and E. L. Karcher. 2015. Short communication: Characterizing metabolic and oxidant status of pastured dairy cows postpartum in an automatic milking system. J. Dairy Sci. 98:7083-7089. https://doi.org/10.3168/ jds.2014-8941.

Gabai, G., S. Testoni, R. Piccinini, L. Marinelli, and G. Stradaioli. 2004. Oxidative stress in primiparous cows in relation to dietary starch and the progress of lactation. Anim. Sci. 79:99-108.

Gesellschaft für Ernährungsphysiologie (GfE). 2001. Ausschuss für Bedarfsnormen der Gesellschaft für Ernährungsphysiologie: Empfehlungen zur Energie- und Nährstoffversorgung der Milchkühe 
und AUfzuchtrinder. DLG-Verlag GmbH, Frankfurt am Main, Germany.

Goff, J. P., and J. R. Stabel. 1990. Decreased plasma retinol, $\alpha$-tocopherol, and zinc concentration during the periparturient period: Effect of milk fever. J. Dairy Sci. 73:3195-3199. https://doi .org/10.3168/jds.S0022-0302(90)79010-8.

Halliwell, B., and J. M. C. Gutteridge. 2015. Free Radicals in Biology and Medicine. Oxford University Press, Oxford, UK.

Miller, J. K., E. Brzezinska-Slebodzinska, and F. C. Madsen. 1993 Oxidative stress, antioxidants, and animal function. J. Dairy Sci. 76:2812-2823. https://doi.org/10.3168/jds.S0022-0302(93)77620 -1 .

Monaghan, P., N. B. Metcalfe, and R. Torres. 2009. Oxidative stress as a mediator of life history trade-offs: mechanisms, measurements and interpretation. Ecol. Lett. 12:75-92. https://doi.org/10.1111/ j.1461-0248.2008.01258.x.

Omidi, A., M. H. Fathi, and M. O. Parker. 2017. Alterations of antioxidant status markers in dairy cows during lactation and in the dry period. J. Dairy Res. 84:49-53. https://doi.org/10.1017/ S0022029916000753.

Pedernera, M., P. Celi, S. C. García, H. E. Salvin, I. Barchia, and W. J. Fulkerson. 2010. Effect of diet, energy balance and milk production on oxidative stress in early-lactating dairy cows grazing pasture. Vet. J. 186:352-357. https://doi.org/10.1016/j.tvjl.2009 .09.003.

Regenhard, P., D. Nakov, and H. Sauerwein. 2014. Applicability of a spectrophotometric method for assessment of oxidative stress in poultry. Maced. Vet. Rev. 37:43-47. https://doi.org/10.14432/j macvetrev.2013.10.002.

Reilly, P. M., H. J. Schiller, and G. B. Bulkley. 1991. Pharmacologic approach to tissue injury mediated by free radicals and other reactive oxygen metabolites. Am. J. Surg. 161:488-503.

Sgorlon, S., G. Stradaioli, G. Gabai, and B. Stefanon. 2008. Variation of starch and fat in the diet affects metabolic status and oxidative stress in ewes. Small Rumin. Res. 74:123-129. https://doi.org/10 .1016/j.smallrumres.2007.04.004.

Sharma, R. K., F. F. Pasqualotto, D. R. Nelson, A. J. Thomas, and A. Agarwal. 1999. The reactive oxygen species-total antioxidant capacity score is a new measure of oxidative stress to predict male infertility. Hum. Reprod. 14:2801-2807.
Sies, H. 1991. Oxidative stress: From basic research to clinical application. Am. J. Med. 91:31S-38S. https://doi.org/10.1016/0002 -9343(91)90281-2.

Sordillo, L. M., and S. L. Aitken. 2009. Impact of oxidative stress on the health and immune function of dairy cattle. Vet. Immunol. Immunopathol. 128:104-109. https://doi.org/10.1016/j.vetimm.2008 .10 .305 .

Speakman, J. R., and M. Garratt. 2014. Oxidative stress as a cost of reproduction: Beyond the simplistic trade-off model. BioEssays 36:93-106. https://doi.org/10.1002/bies.201300108.

Spiekers, H., T. Ettle, T. Jilg, B. Kuhla, U. Mohr, and M. Pries. 2018. Grobfutterleistung von Milchkühen und Futterertrag - Auswertung der Versuchsdaten des Verbundprojektes optiKuh. VDLUFASchriftenreihe (75/2018):334-341.

Sugino, N. 2006. Roles of reactive oxygen species in the corpus luteum. Anim. Sci. J. 77:556-565. https://doi.org/10.1111/j.1740 $-0929.2006 .00386 . x$.

Urban-Chmiel, R. 2006. The influence of transport stress on oxidative stress parameters in bovine leukocytes. Slovakia Vet. Res. $43: 243-246$

Urh, C., J. Denißen, I. Harder, C. Koch, E. Gerster, T. Ettle, N. Kraus, R. Schmitz, B. Kuhla, E. Stamer, H. Spiekers, and H. Sauerwein. 2019. Circulating adiponectin concentrations during the transition from pregnancy to lactation in high-yielding dairy cows: Testing the effects of farm, parity, and dietary energy level in large animal numbers. Domest. Anim. Endocrinol. https://doi.org/10 .1016/j.domaniend.2019.01.001.

Wathes, D. C., Z. Cheng, N. Bourne, V. J. Taylor, M. P. Coffey, and S. Brotherstone. 2007. Differences between primiparous and multiparous dairy cows in the inter-relationships between metabolic traits, milk yield and body condition score in the periparturient period. Domest. Anim. Endocrinol. 33:203-225. https://doi.org/10.1016/j .domaniend.2006.05.004

Wullepit, N., K. Raes, B. Beerda, R. F. Veerkamp, D. Fremaut, and S. de Smet. 2009. Influence of management and genetic merit for milk yield on the oxidative status of plasma in heifers. Livest. Sci. 123:276-282. https://doi.org/10.1016/j.livsci.2008.11.013. 